\title{
ASPECTS OF SOME CHARACTERISTICS OF LETTUCE VARIETIES GROWN IN SOLAR IN PITESTI
}

\author{
Florina Uleanu ${ }^{1 . *}$, Mihaela Ileana Oprea ${ }^{1}$, Marinel Iordache ${ }^{2}$, Adriana Bădulescu ${ }^{3}$ \\ ${ }^{1}$ University of Pitesti, Târgul din Vale Street, no 1, Piteşti, Romania \\ ${ }^{2}$ Eng. University of Pitesti, Târgul din Vale Street, no 1, Piteşti, Romania \\ ${ }^{3}$ PhD., INCDBH Ștefănești-Argeș, Romania
}

\begin{abstract}
The aim of this paper was to observ the differences between three lettuce varieties, Silișteană C, Lollo Rosso and Lollo Bionda, in terms of growth and development. Experimental research activity was carried out in the solar belonging to S.C. Salpitflor Green S.A. Pitești. Were monitoried parameters such as: plant height, number on leaf on the plant, the diameter of the rosetts of leaves, the weight of leaf rosette, the lenght of the root system and the weight of the root system. The result were compared and recomandations were made. The three lettuce varietes reacted differently, generally the differences between the values of the different characters measures being very obvious. Higer results for all studied characters were obtained in the Silișteană $C$ variety, compared to the other studied varietes, denoting that it is a valuable, vigorous and balanced variety. In all the studied characters, the Lollo Bionda variety recorded the lowest values, showing a lower quality than the other variants.
\end{abstract}

Keywords: growth, lettuce, solar, variety.

\section{INTRODUCTION}

Salad has always been a reason for study for researchers in order to obtain high value varietes and hybrids, because it is a vegetable with high nutritional importance (Chaux and Foury, 1994), rich in vitamins, minerals and nutrients (Maniutiu, 2006, Janbaz et al., 2013).

A tendency to make salad culture more efficient is represented by the specialization of the crops depending on the destination of the production (Ciofu et al., 2004, Křístková et al., 2008). Important benefits are brought by the use of early and disease-resistant varieties and hybrids, (SretenovićRajičić et al., 2008), reducing production costs. In this way, early productions are obtained that are capitalized at advantageous prices ().

As a result of the widening of the lettuce variety, it is necessary to study the varieties in comparative crops in order to see how their genetic development is expressed in the conditions of the area in which they are cultivated (Vries, 1990).

\section{MATERIALS AND METHODS}

The experience was performed in the solarium at S.C.Salpitflor Green S.A., located in Pitești, Argeș County. 


\section{Current Trends in Natural Sciences}

Vol. 9, Issue 18, pp. 171-175, 2020

https://doi.org/10.47068/ctns.2020.v9i18.023

Current Trends in Natural Sciences (on-line)

The biological material consisted of three varieties of lettuce: Silișteană C, Lollo Rosso and Lollo Bionda.

Silișteană C: romanian variety, produced by S.C. UNISEM S.A. Bucharest, I.S.T.I.S.

Lollo rosso: early cultivar, recomended for open field cultivation. The leaves are curly, dark red on the outside and green on the inside and are very pleasant to the taste. The average weight is between 150-300 g. Intended for fresh consumption.

Lollo bionda: early cultivar, recommended for open field cultivation. The leaves are curly, light green and very pleasant to taste. The average weight is between 150-300 g. Intended for fresh consumption.

The objective of the research was to follow the differences between the varieties. Comparisons were made regarding the biometric parameters for each studied variant, following their commercial value.

\section{RESULTS AND DISCUSSIONS}

In terms of the number of leaves, the Silișteană C variety was noticed, with superior result to the other variants. The smallest number of leaves was recorded by the Lollo Bionda variety (Figure 1). The high frequency of leaves/plant to the Silișteană C variety, 2.55, indicates the obtaining of vigorous and quality edible parts (Figure 2).

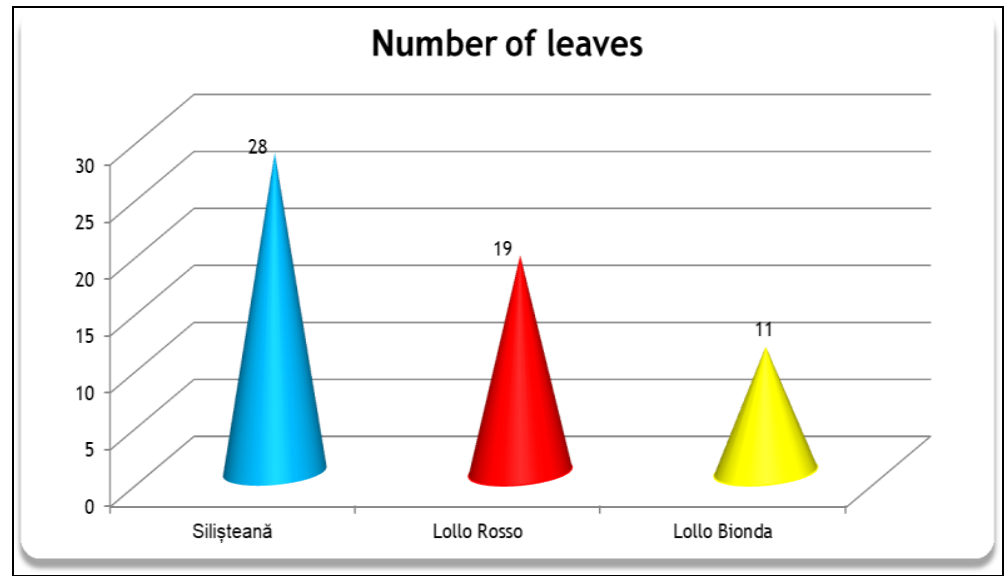

Figure 1. The number of leaves in the three varieties study: Silișteană C, Lollo Rosso and Lollo Bionda

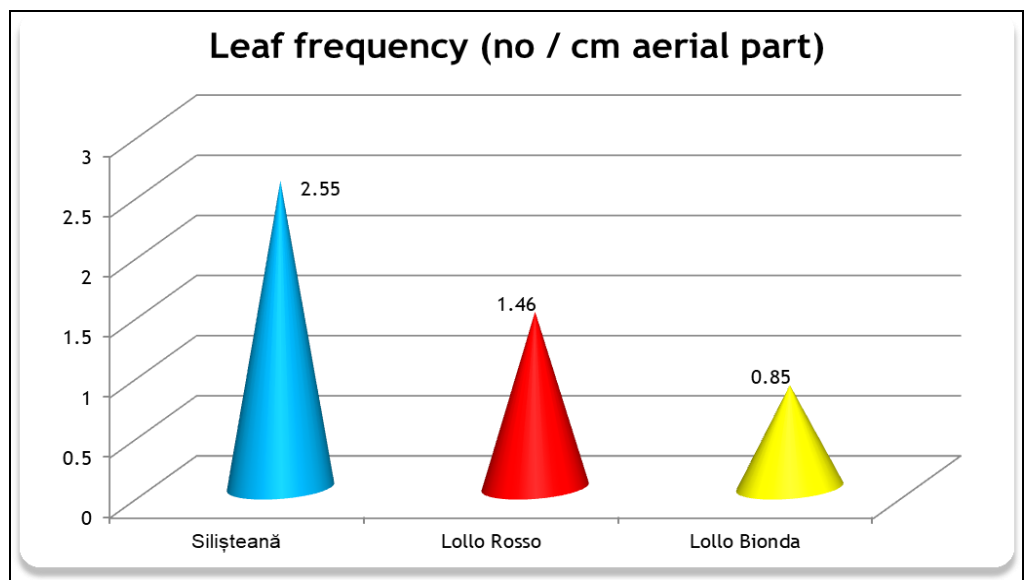

Figure 2. Leaf /plant frequency for the three studied varietes 


\section{Current Trends in Natural Sciences}

Vol. 9, Issue 18, pp. 171-175, 2020

https://doi.org/10.47068/ctns.2020.v9i18.023

Current Trends in Natural Sciences (on-line)

ISSN: 2284-953X

Current Trends in Natural Sciences (CD-Rom)

ISSN: 2284-952

ISSN-L: 2284-9521

ISSN-L: 2284-9521

The variety influenced the growth in height of the leaf rosette. The best results were obtained for the Silisteană $\mathrm{C}$ variety, where the height of the rosette was $15 \mathrm{~cm}$, compared to the other two varieties, that obtained $13 \mathrm{~cm}$ in height (Figure 3).

The Silișteană C variety also recorded the largest diameter of the leaf rosette (Figure 4, Figure 5).

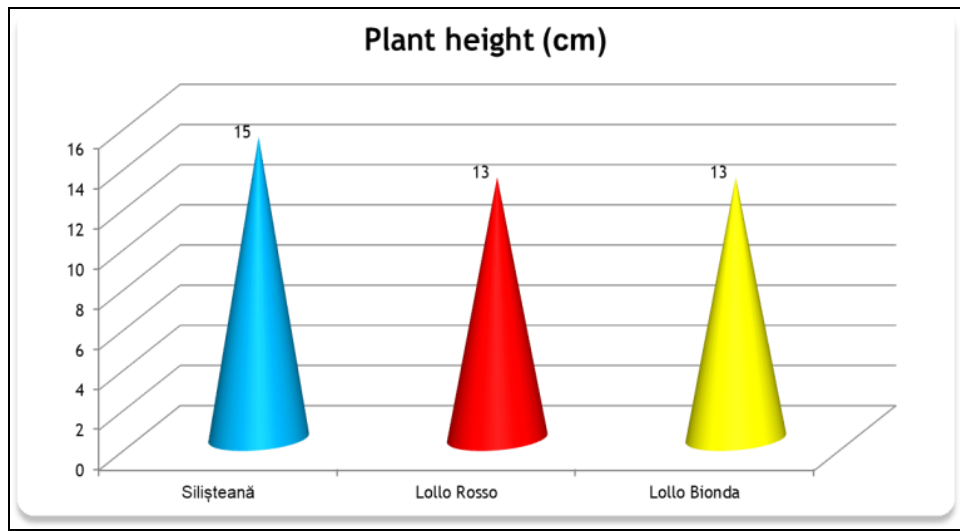

Figure 3. Leaf rosettes height for Silișteană C, Lollo Rosso and Lollo Bionda varietes

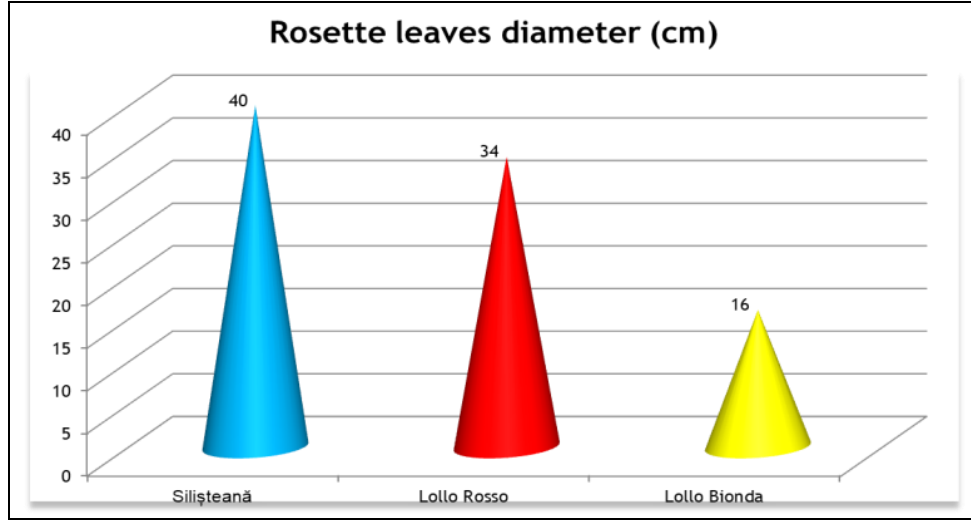

Figure 4. Diameter of leaf rosettes at Silișteană C, Lollo Rosso and Lollo Bionda varietes

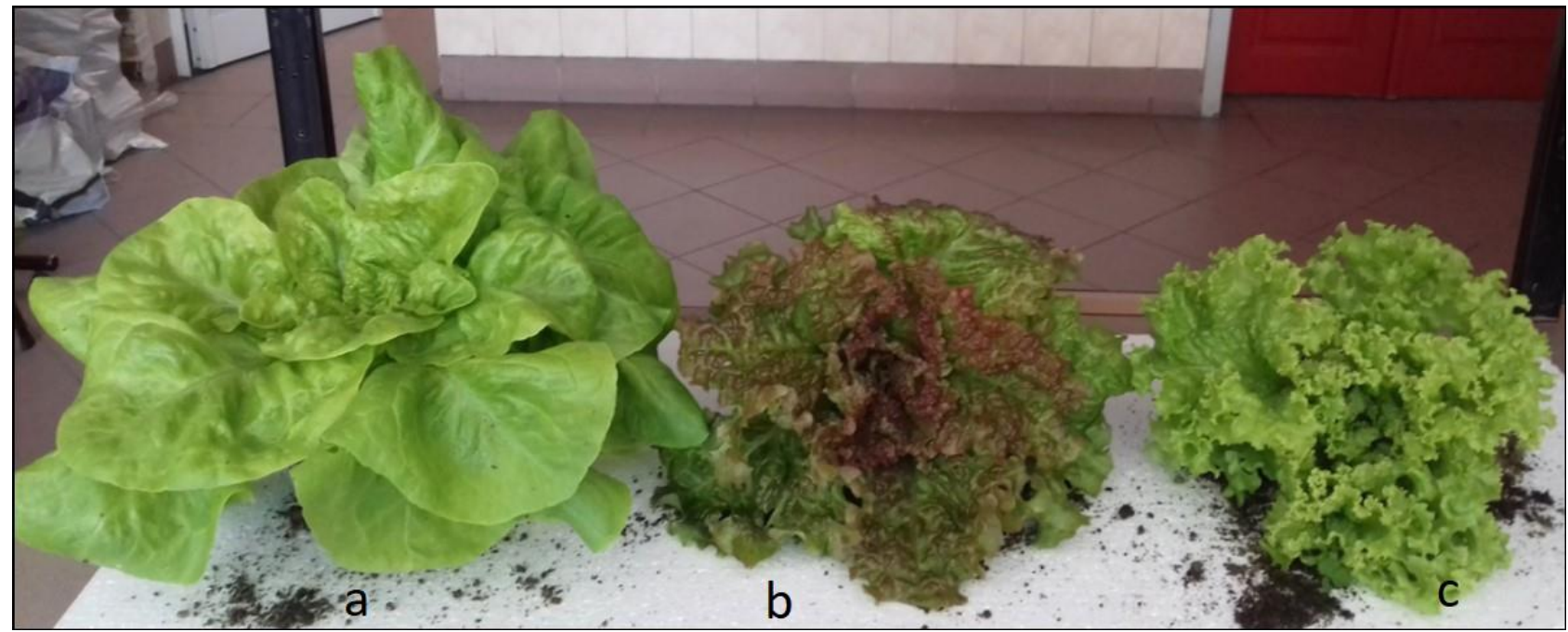

Figure 5. The diameter of the leaf rosettes at the studied varieties: Silișteană C (a); Lollo Rosso (b); Lollo Bionda (c) 


\section{Current Trends in Natural Sciences}

Vol. 9, Issue 18, pp. 171-175, 2020

https://doi.org/10.47068/ctns.2020.v9i18.023

Current Trends in Natural Sciences (on-line)

ISSN: 2284-953X

Current Trends in Natural Sciences (CD-Rom)

ISSN: 2284-9521

ISSN-L: 2284-9521

ISSN-L: 2284-9521

Regarding the weight of the leaf rosette, it can be appreciated that the best results were registered for the Silișteană C variety which indicate the obtaining of vigorous and quality plants (Figure 6).

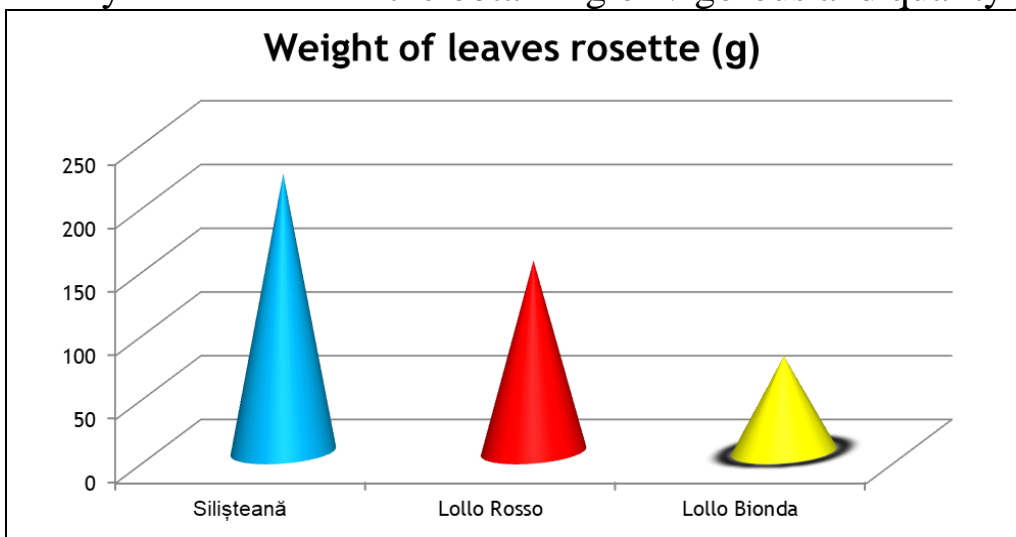

Figure 6. The weight of the rosettes of leaves in the studied varietes

The best results in terms of the root system were obtained in the Silișteană C variety, to which the length of the roots was almost 2 times longer, compared to that of the roots of the Lollo Bionda variety, demonstrating a better nutritional capacity (Figure 7).

And in terms of the weight of the root system, the best results were also recorded to the Silișteană C variety and the weakest results were obtained to Lollo Bionda variety (Figure 8).

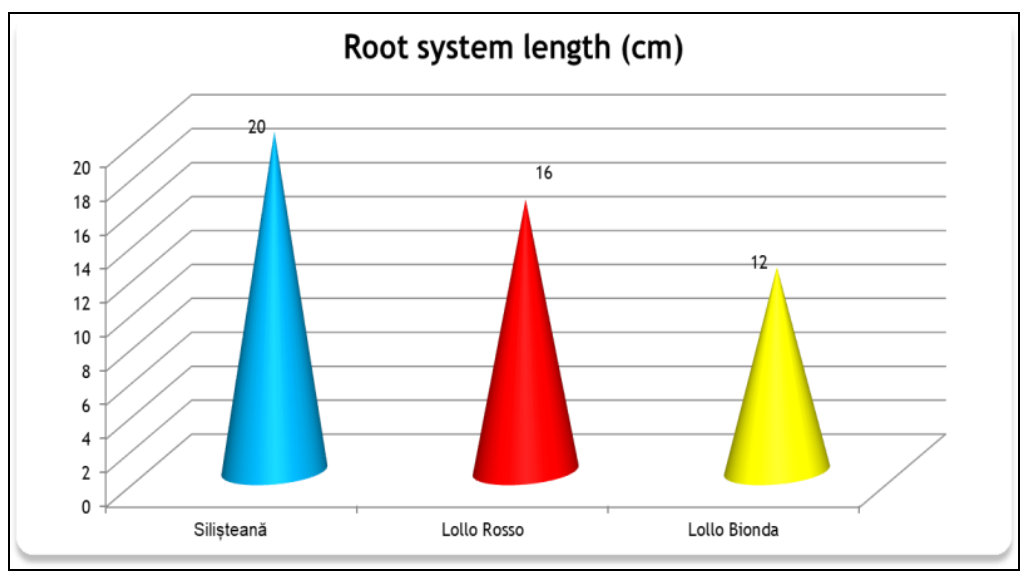

Figure 7. Root system lenght at Silișteană C, Lollo Rosso and Lollo Bionda varietes

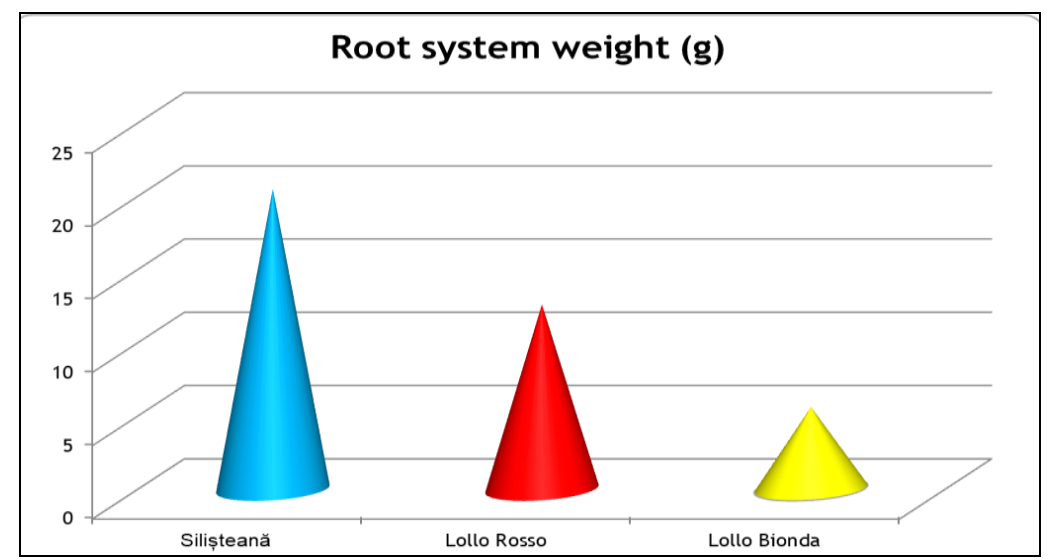

Figure 8. Root system weight at Silișteană C, Lollo Rosso and Lollo Bionda varietes 


\section{CONCLUSIONS}

Following the observations, the Silișteană C variety was noted for its vigorously, balanced and special commercial aspect. The measurements performed showed thet the superior results for all the studied characters were obtained for the Silișteană C variety, compared to the other varieties. In all the characters studied, the Lollo Bionda variety recorded the lowest values, showing a lower quality than the other variants.

\section{REFERENCES}

Chaux, C., Foury, C. (1994). Les productions légumières [Vegetable productions], vol. III. Paris:Ed. Lavoisier TEC ET DOC.

Ciofu, R., Nistor, S., Popescu, V., Chilom, P., Apahidean, S., Horgoş, A., Berar, V., Lauer, K.F., Atanasiu, N. (2004). Tratat de Legumicultură [Vegetable treaty].Bucharest, Ceres Poublishing House.

Cross, R.J. (1998). Review paper: global genetic resources of vegetables. Plant Varieties \& Seeds, 11, 39-60.

Janbaz, K.H., Latif, M.F., Saqib, F., Imran, I., Zia-Ul-Haq, M., De Feo, V. (2013). Pharmacological Effects of Lactuca serriola L. in Experimental Model of Gastrointestinal, Respiratory, and Vascular Ailments. Evidence-based Complementary and alternative medicine:Ecam, 04 Apr 2013, 2013:304394, from https://europepmc.org/.

Křístková, E., Doležalová, I., Lebeda, A., Vinter, V., Novotná, A. (2008). Description of morphological characters of lettuce (Lactuca sativa L.) genetic resources. Hort. Sci. (Prague), 35, 2008 (3), 113-129.

Măniutiu, D. (2006). Cultura legumelor [Vegetable products].Cluj-Napoca: AcademicPres Poublishing House.

Popescu, V., Popescu, A. (2008). Cultura legumelor în sere şi solarii [Growing vegetables in greenhouses and solariums].Bucharest: M.A.S.T. Poublishing House.

Sretenović-Rajičić, T., Hintum, Th. .J.L. van, Lebeda, A., Dehmer, K.J. (2008). Analysis of wild Lactuca accessions: Charakterization and utilization, conservation and identification of redundancy. Plant Genetic Resources, 6, 153163.

Vries, I.M. DE. (1990). Crossing experiments of lettuce cultivars and species (Lactuca sect. Lactuca, Compositae). Plant Systematics and Evolution, 171, 233-248. 